\title{
FAMILY PROTECTION UNDER PUBLIC AND PRIVATE LAW IN HUNGARY
}

\section{EDIT SÁPI}

This book chapter presents constitutional and private law (civil law) approaches to family protection and relations. The former serves as a basic introduction and covers the most relevant legal sources on the topic and offers a constitutional interpretation as provided by the Constitutional Court. The latter examines the private law approach to family protection, with a special emphasis on family law norms. The article deals with legally recognized relationships and rules governing parent-child relationships. Family protection is analyzed from the perspective of family law and related legal institutions.

\section{The constitutional approach to family protection}

The first and original version of art. L) of the Fundamental Law of Hungary described the protection of marriage and family as follows: "Hungary shall protect the institution of marriage, the conjugal union of a man and a woman based on voluntary and mutual consent; Hungary shall also protect the institution of the family, which it recognizes as the basis for survival of the nation." Besides the Fundamental Law, the Act on the Protection of Family (Act CCXI of 2011) (Csvt.), which entered into force on January 1, 2012, also stipulated that raising children in a family is safer than any other option. A family can fulfill its role if the strong relationship between the parents expands to include their responsibility toward their child. There is no

Edit Sápi (2021) Family Protection Under Public and Private Law in Hungary. In: Tímea Barzó, Barnabás

Lenkovics (eds.) Family Protection From a Legal Perspective, pp. 111-150. Budapest-Miskolc, Ferenc Mádl Institute of Comparative Law-Central European Academic Publishing. 
sustainable development and economic growth without the birth of children. The Declaration of the rights and duties of parents and children is an integral part of the Act and will be described later. Section (1) of Paragraph 7 of the Csvt. originally stated that the basis of a family is marriage between a man and a woman or the direct line of kinship or family placement guardianship. Decision No. 43/2012. (XII. 20.) of the Constitutional Court stated that this segment under the Act violates the Fundamental Law. According to the Constitutional Court, the legislature took the opportunity in the Family Protection Act to redefine an institution governed by Fundamental Law, which occupies a lower position among the legal sources, without listing, separately or possibly under other names, other forms of social coexistence recognized by law owing to which families are entitled.

If the legislature intended to highlight and set one form of cohabitation as a model, he is still obliged to guarantee the same level of protection for other forms as recognized by law, because of his obligation to protect the institution. ${ }^{1}$ According to the decision of the Constitutional Court, if the legislature wishes to establish rights and obligations for families, then those who wish to establish a family in another permanent emotional and economic community before or without marriage cannot withdraw rights that have been already granted, must not reduce the existing level of protection of the form of partnership, and must protect the institution in the same way, especially in connection with the best interests of the child. It is a requirement of the Fundamental Law that the obligation of institutional protection affecting marriage and family may not result in any direct or indirect discrimination against children on the ground that their parents are brought up in a marriage or other type of cohabitation. ${ }^{2}$

Consequently, before the Fourth Amendment of the Basic Law, the concept of the family covered, not just a family based on marriage, but that in the sociological sense as well. The body established the unconstitutionality of the sections of the Family Protection Act defining the family, while taking into account the level of legal sources at the end of 2012. Since then, the definition of the family relationship based on marriage was included only in the Family Protection Act. The contradiction was resolved by the Fourth Amendment of the Basic Law, in which the following is mentioned: "the basis of the family relationship is marriage or the parent-child relationship." However, this definition excludes de facto partnerships and children born from them, from the concept of family and, indirectly, from family protection. In such cases, the parents are considered the family of the common child, but the family relationship is not established between the parties. ${ }^{3}$ The question then arises: Should our perception

1 It did not follow from art. L) of the Fundamental Law that, for example, those cohabitants who take care of and raise each other's children, but do not or cannot have a common child because of other circumstances (being elderly or infertile), persons caring for their siblings, possibly grandchildren, grandparents raising their grandchildren, and many based on lasting emotional and economic communities would not be subject to the same objective obligation of the state to protect the institution, no matter what the legislature may call them.

2 Barzó, 2017b, pp. 4-7.

3 Barzó, 2017a, pp. 41-44. 
and the legal concept of family change as social and human relations change? Is the concept of family eternal? According to the text of the Fundamental Law, the answer is obvious. ${ }^{4}$

\section{Legally recognized relationship forms}

For a long time, Hungarian family law considered the institution of marriage the basic unit of family. However, changes in society have made it necessary to provide legal protections for other forms of social cohabitation as well. In the recent decades, we have been faced with the social fact that the marriage-based family model on which the family law system is built is being preferred less and less. The growth of cohabitation is a social trend and Hungarian legislation could not ignore it, either.

\subsection{Legal history of the regulation of de facto cohabitation}

The socialist approach considered cohabitation without marriage a phenomenon that is incompatible with its morals; thus, only the basic unit of society, the family, can be established by marriage. ${ }^{5}$ Views that promoted the equal protection of marriage and extramarital affairs were not accepted at the time because it was feared that it would render the institution of marriage empty, which was contrary to the Constitution at the time. ${ }^{6}$ However, in 1951, the first uniform social security legislation granted a widow's pension on equal terms to the wife to a partner who had lived with the deceased for at least a year before his death and had at least one child in the course of such cohabitation. ${ }^{7}$ However, the definition of the legal concept and conceptual elements of cohabitation and the development of normative material for the legal institution were absent. ${ }^{8}$

Act IV of 1952 on Marriage, Family, and Guardianship (Csjt.) did not provide for any form of personal or property relations among cohabitants and denied the place and significance of the legal institution in family law. However, Hungarian society and law had to face the fact that marriage was increasingly being pushed into the background with a growing number of couples opting for cohabitation. ${ }^{9}$ For the first time, a concrete legal regulation concerning cohabitants was set out in Act

4 Rácz, 2019, p. 35.

5 Nizsalovszky, 1963, p. 67.

6 Bajory, 1959, p. 208.

7 Section 15(2) of the Act 30 of 1951 on the uniform social security pension for employees.

8 Hegedús, 2010, p. 22.

9 Kőrös, 2005, p. 1. 
IV of 1977, which was based on PK $94 .{ }^{10}$ This amendment inserted the concept of a cohabitant into the Part of Companies (Section 578.§) of Act IV of 1959 on the Civil Code. This part was effective from which took effect from March 1, 1978 as follows: "the spouses-woman and man living together without marriage, in a common household, in an emotional and economic community-acquire joint ownership during their cohabitation in proportion to their contribution to the acquisition. If the contribution rate cannot be determined, it shall be deemed to be equal. Working in the household counts as a contribution to the acquisition." These rules should be applied to the property relations of other relatives living in the same household, apart from spouses. With this, cohabitants were included within the law on obligations under the Civil Code and cohabitation was considered similar to an atypical civil law company. ${ }^{11}$ However, the legislature has been dealing with the issue consistently. Regulations under the Civil Code of 1959 were amended through Act XXV of 1988, which incorporated Paragraph 578/G. However, this modification did not result in any substantive change, but only reorganized the rules on cohabitation.

The Constitutional Court in No. 14/1995. (III.13.) stated that the institution of marriage is traditionally a cohabitation between men and women in both culture and law. This partnership aims at childbirth and child-rearing and serves as a framework for spouses to live in mutual care and support. The ability to bear and give birth to children is not a conceptual element or condition for marriage, but it can be regarded as an original and typical purpose of marriage. However, the Constitutional Court emphasized in the decision that the long-term cohabitation of two persons can achieve such values that they can claim legal recognition for, regardless of their gender, based on equal consideration of the personal dignity of the individuals involved.

After the Constitutional Court's decision, Act XLII. of 1996 amended the Civil Code of 1959, following which the first sentence of Section 578/G(1) stated thus: "During their cohabitation, the spouses acquire joint ownership in proportion to their contribution to the acquisition." The amendment also introduced a new definition for cohabitation, which was placed under the "Closing Provisions" of the Civil Code of 1959:12 "Unless otherwise provided by law cohabitants are, two persons living together in a common household, emotional and economic community without marriage," regardless of their gender. ${ }^{13}$ The proportion of out-of-wedlock births in Hungary increased in the decade after the turn of the millennium, and reached the highest value ever measured, namely $47.8 \%$ in 2015 .

10 According to PK Resolution No. 94, "family relations may exist not only between spouses and blood relatives, but also between persons of the opposite sex who live together in the manner of spouses and without marriage". Repealed by the Resolution PK No. 272.

11 Hegedús, 2006, pp. 10-11.

12 The definition was changed by the 1996 and 2009 amendments of the Civil Code. It was transferred to the "Closing Provisions" of the Civil Code. The first amendment recognized the cohabitation of same-sex couples following the decision of the Constitutional Court. Körös, 2013a, pp. 6.

13 Kuti, 2016, pp. 7-8. 
Number of births between 1919 and 2019

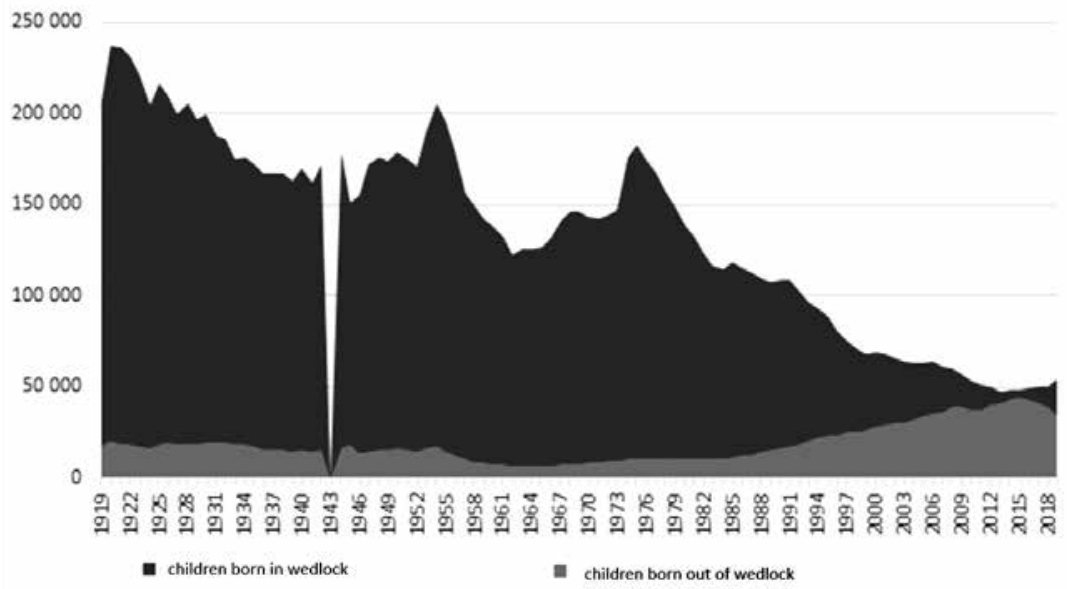

This can be traced back to the strong growth of extramarital partnerships and increasing courage among people who lived in such partnerships and had children out of them. Between 2001 and 2016, the number of people who chose to live in cohabitation more than doubled. ${ }^{14}$

\section{Ratio between marriage and cohabitation in 2001}

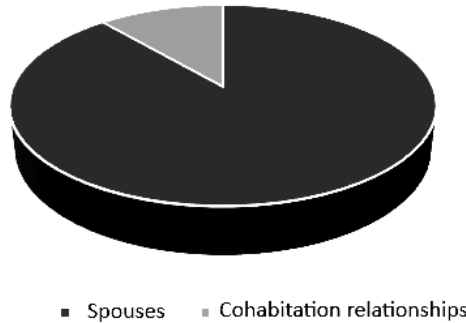

Ratio between marriage and cohabitation in 2016

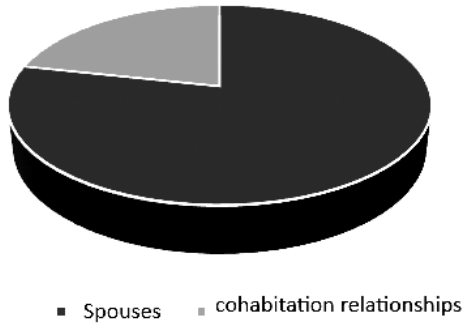

At the same time, a sharp decline in the number of marriages was seen. In the 1970 s, the number of marriages were between 90,000 and 100,000, whereas in 2010, 355,000 marriages, were bounded. The latter data meant a local minimum, so it was one of the lowest number in the history of volt population statistics. ${ }^{15}$

14 According to the legal literature, most cohabitants consider their relationship a "probationary marriage." See e.g., Spéder, 2004, pp. 137-151. Bukodi, 2002, pp. 227-251.

15 There has been an increase over the last six years. In 2015, there were 459,000 marriages. Népmozgalom, 2015, pp. 3-4. 
Number of marriages concluded between 1919 and 2019

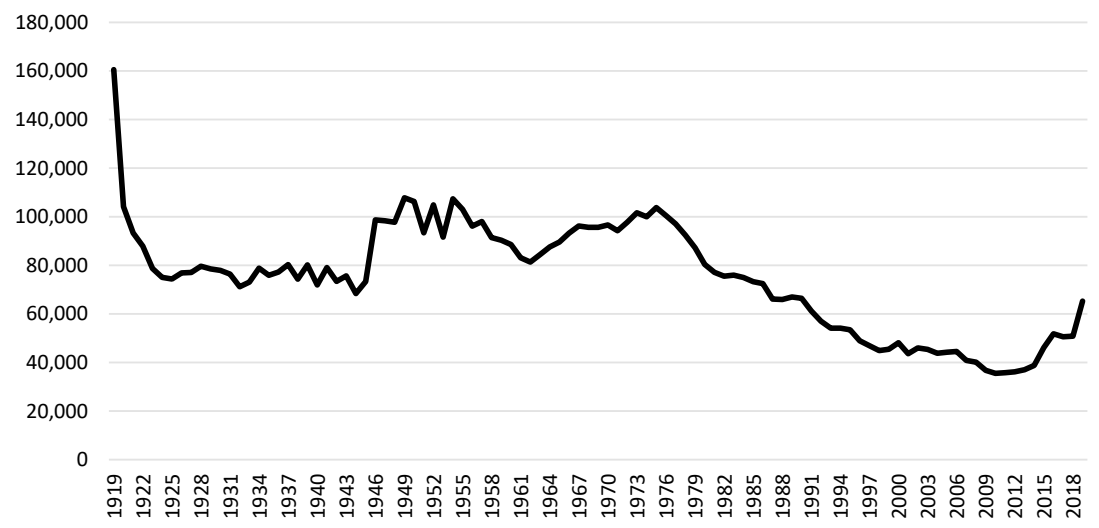

The number of disputes to which "traditional" matrimonial property and other family protection rules were no longer automatically applied increased with the expansion of the family to include cohabiting couples and their children. Consequently, mothers and, less often, fathers, who were left alone with their children after the cessation of cohabitation became more vulnerable.

Accordingly, the regulation of cohabitation was heavily debated when the Civil Code was codified. An increasing number of cohabitants who lived like spouses, usually with their children (or one of their children), formed a family. They chose this instead of marriage in order to incur lower costs. Accordingly, the Concept of the Civil Code, which was published in 2003, clearly emphasized on the inclusion of cohabitation in the Family Law Book. It sought to grant the other cohabitant a right of maintenance in the case of certain conditions and a right to use the common apartment as legal inheritance. ${ }^{16}$ The proposed legislation would not have raised the protection of cohabitation to the level of marriage, but would have provided additional rights compared to the law in force at the time. Within the property relations of the spouses, it proposed a more flexible public acquisition regime than joint ownership as a legal property system. In comparison, the amended Civil Code in force at present has completely changed the rules governing de facto partnerships. The legislature split the rules that were coherent in the Expert Draft in such a way that the definition of cohabitants and property law consequences of cohabitation were incorporated into the Book of the Law of Obligation ( $6^{\text {th }}$ Book of the Civil Code), but the rules on maintenance and the right to dwelling can be found in the Family Law Book ( $4^{\text {th }}$ Book of the Civil Code) under the title "Family law effects of de facto partnership".

Cohabitation will result in family law effects-maintenance and the right to dwelling - only if the partners live together for at least for one year and have a "common child." If the spouses do not have a common child, despite living together for long, 
having their own individual children and running a household together, and contributing to each other's business, the family law effects do not exist. ${ }^{17}$ Cohabitation in a common household within an emotional and economic community creates a family relationship without marriage which is not connected to the characteristics of a contract. ${ }^{18}$ Contrary to the Expert Draft, the new Civil Code abandoned the obligation of supporting and working together in order to achieve a common goal. Nevertheless, it is obvious that the law shall require mutual solidarity between the parties in a de facto partnership as well, just as in all relationships, which was fully recognized over several decades of judicial practice. ${ }^{19}$

\subsection{History of the introduction of registered partnerships}

Same-sex relationships, homosexuality, and sexual orientation are significant characteristics of the human identity. They have been addressed over the last 30 years through both legal interpretation and the exercise of rights. The process led to the decriminalization and open acceptance of homosexuality, and the prohibition of discrimination on the ground of sexual orientation, to the point that public recognition of same-sex relationships emerged.

In 1989, Denmark became the first country to allow same-sex couples to have their relationships recognized by the state. ${ }^{20}$ In Hungary, the near-complete elimination of gender discrimination in relation to optional forms of partnership resulted from the enactment of the Act CLXXXIV of 2007 on registered partnerships (Bét. I.). Bét. I. would have come into effect on January 1, 2009. It recognized registered partnerships as family law institutions and listed out rules that differed from those that applied to marriage. On the lines of French and Dutch legislation, the Bét. I. allowed all adults to have a registered partnership regardless of their sex and sexual orientation. ${ }^{21}$ Decision No. 154/2008 (XII.17.) of the Constitutional Court emerged in response to the Act and declared that the "establishment of a registered partnership for same-sex persons is not unconstitutional." However, the concrete legislative solution was not in line with the Constitution. Thus, the Act was annulled. The problem was that the legislature did not find any difference between the registered partnership between same-sex and heterosexual persons and applied only a general reference rule to marriage. With this, the legal institutions of marriage and registered partnerships, and registered partnerships between same-sex and heterosexual persons were made uniform. For heterosexual people, the application of registered partnership would have meant the doubling of marriage and the "devaluation" of marriage. Therefore, the Constitutional Court instructed the legislature to "maintain a distance" between

17 Kriston, 2014, p. 36.

18 Kriston, 2016, pp. 235-236.

19 BH 2005.141.; BH 2013.217.

20 Novák, 2016, pp. 29-30.

21 Kriston, 2019, pp. 91. 
marriage and cohabitation among men and women, and to distinguish between marriage and registered same-sex cohabitation. Thus, the Constitutional Court ruled that the Bét. I. was unconstitutional and annulled it. Consequently, the Bét. I. did not enter into force on January 1, 2009.

Act XXIX of 2009 on registered partnership and the amendment of the proof of cohabitation relationship (Bét. II.) was enacted based on the abovementioned Constitutional Court Decision and remains in force. Without prejudice to the separate law, the Committee's proposal for a new Civil Code sought to lay down the most important rules for the establishment, termination, and family law consequences of a registered partnership in the Family Law Book. The Government submitted the bill to the Parliament in accordance with the Commission Proposal. ${ }^{22}$ The text of the Civil Code, which was adopted following the amendments, and that remains in force, is surprising and did not provide well designed changes. ${ }^{23}$ Registered partnerships have been completely removed from the Civil Code such that the Act does not mention it in the definition of "relative" 24 and in the impediments to marriage, either. It can be only found in the circumstances that preclude the existence of effective cohabitation. ${ }^{25}$ However, this does not mean that registered partners have fallen out of the scope of protection under the Civil Code. Section (1) of Paragraph 3 of the Bét. II. is still in force, because it comprises a general reference that the rules on marriage shall be applied to registered partnerships with exceptions regulated by law. Registered partners have all the rights and obligations that are attached to marriage in relation to personal and property rights and obligations fixed in the Civil Code and with this solution, the rules of marriage form the background for registered partnerships. ${ }^{26}$

\section{The current regulation of legally protected relationships in Hungary}

According to the law in force, it is possible to live in a relationship as a legal institution, in the form of a marriage or registered partnership in Hungary. However, we have to mention that de facto cohabitation ${ }^{27}$ is regulated as a contractual relationship in the Book of Obligations of the Civil Code does not require a formal procedure, like in the case of marriage, because starting a life community is sufficient for the existence of a cohabitation relationship. Proving the existence of cohabitation

23 See the critical analysis by Vékás, 2013, pp. 1-7.

24 CC. 8:1.§ 1.2. point

25 CC. $6: 514 . \S(1)$.

26 Kőrös, 2013a, p. 7.

27 In the legal literature, family law issues of de facto cohabitation seem divisive. See: Kriston, 2016, pp. 226-239.; Kriston, 2018a, pp. 401-406.; Kriston, 2019a, pp. 101-109. 
is extremely complex, and the legislature sought to ease this by establishing the Register of Cohabitation Declarations (cohabitation register) from January 1, 2010 onwards. The Hungarian Chamber of Notaries maintains the Register. The cohabitation register contains declarations that serve as a proof of existence of a cohabitation relationship. These declarations include:

a) a statement that was made jointly by two non-incapacitated adults before a public notary to the effect that they are in a cohabitation relationship with each other under the Civil Code, and

b) a statement by at least one of the applicants before a notary that (s)he no longer has a partnership with the person previously registered with him or her.

The cohabitation register certifies the existence of a cohabitation relationship between those who make such joint declarations. However, the cohabitation register does not prove the existence of a partnership if a partner has subsequently made a declaration of non-existence in the partnership register, or if one of the partners has died, or if either partner has subsequently married or entered into a registered partnership. ${ }^{28}$ However, the recognition of the statutory scope does not preclude the fact that the authority examines the substance of the partnership. ${ }^{29}$

\subsection{Establishment and definition of certain relationship forms}

\subsubsection{Marriage}

The Family Law Book of the Hungarian Civil Code declares that marriage shall be considered contracted if a man and woman appear together before the registrar in person and declare their intention to marry. This results personal and property legal effects. Such a declaration cannot be subject to a condition or time limit. After the exchange of wedding vows, the registrar shall declare the parties united in marriage and record the fact of marriage in the marriage registry (declarative effect). ${ }^{30}$ The Family Law Book also regulates the formalities of marriage, which do not affect the existence (validity) of a marriage. These are the following: two witnesses, office of the local authority and publicly.

According to the Family Law Book, proceedings for the conclusion of marriage can be divided into two parts: actions before marriage and the conclusion of the marriage itself. Actions before marriage are regulated by laws on the procedure involved in maintaining a civil register. ${ }^{31}$ Marriage begins with the announcement of the intention to marry. The spouses are obliged to declare their intention to marry jointly and in person, and the registrar draws up a protocol on it with the

28 Section 36/E. § (1)-(3) of the Act XLV of 2008, on the non-litigation procedures of public notaries

29 EBH2015. K.27. II.

30 CC. $4: 5 . \S(1)-(2)$.

31 Act I. of 2010. on civil register (At.). 
data content specified by law. If the spouses prove that the legal conditions for their marriage are met and state that, according to their knowledge, there is no obstacle to the marriage ${ }^{32}$ the parties shall wait for the mandatory waiting period of 30 days, according to the law. In justified cases, the notary is entitled to grant an exception from the 30-day waiting period. According to Section (3) of Paragraph 4:7 of the CC where either of the parties to the marriage suffers a terminal illness, the statement of the parties shall suffice in place of verifying all legal requirements of marriage. Marriage may be contracted immediately upon notification. The Family Law Book does not expressly regulate the age limit for marriage, but only states that marriage concluded by a minor is invalid; consequently marriage can be established between people aged 18 years and above. However, a guardian may authorize the marriage of a minor with limited legal capacity, that is, aged above 16 years. ${ }^{33}$

\subsubsection{Registered partnership}

Registered partnership is a family relationship between persons of the same sex that establishes personal status and has the same characteristics as marriage between persons of different sexes. ${ }^{34} \mathrm{~A}$ registered partnership can be concluded between two persons of the same sex who have reached the age of 18 years together. Such individuals may enter a registered partnership before the registrar if they mutually state their intention to do so with each other. Other formal requirements include publicity (which means a public place in general) and presence of two witnesses. ${ }^{35}$ The elements of the definition are almost identical to the formal requirements of marriage. However, a registered partnership can only be concluded by persons aged above 18 years. In the case of people aged over 16 years but under 18 years, the guardian cannot grant permission to establish such a relationship. After the registered partners' statement, the registrar incorporates the fact of establishing the relationship in the register. The registration, just as in the case of a marriage, has a declaratory effect. Similar to the actions prior to marriage, according to the actions prior to the establishment of a registered partnership, prospective registered partners shall declare before the registrar that, to their best knowledge, there is no legal impediment to their registered partnership and that they shall justify that the legal conditions for their registered partnership exist. ${ }^{36}$

32 Art. 17. § (1)-(5).

33 CC. $4: 9$. § (1)-(2).

34 Csû́ri, 2010, p. 13.

35 Bét. II. 1. § (1)-(4).

36 A total of 67 and 80 partnerships were concluded in the second half of 2009 and 2010, respectively. Until 2013, when 30 registered partnerships were concluded, the number of partnerships decreased each year. In 2014 there were 42, and in 2015 there were 65 partnerships (36 between men and 29 between women). Népmozgalom, 2015, p. 5. 


\subsubsection{De facto partnership}

De facto partnership refers to a partnership where two people live together outside of wedlock in an emotional and financial community in the same household ("cohabitation"), provided that neither of them is engaged in wedlock or partnership with another person, registered or otherwise, that they are not related in direct line, and that they are not siblings. ${ }^{37}$ Different sex of the partners is not a requirement, so a de facto partnership can be established between same-sex partners, as well. The definition enumerates positive requirements and exclusionary conditions in order to establish such a relationship. ${ }^{38}$ Although the legislature aimed to provide a precise definition of cohabitation, the interpretation of individual conceptual elements remains unclear. These areas have been addressed by judicial practice. ${ }^{39}$

a) The existence of emotional community between the parties. The emotional side covers the partners' emotions toward each other and the resulting obligation to support and cooperate with each other. The Curia (Supreme Court of Hungary) also drew attention to the importance of solidarity and the obligation to support. ${ }^{40}$

b) Economic community between the parties. Economic community can be founded if the parties manage their everyday economic goals together in order to achieve their future economic goals. ${ }^{41}$ It also means cooperation in major property-related activities and the use of income for common purposes. The parties should cooperate not only in the acquisition of assets, but also in their economic objectives, which must be shared throughout the life of the community and their income should be used together for these purposes. ${ }^{42}$ Before the CC came into effect, case law focused on the concentration of property in some form, because legal property relations between de facto partners were based on a system of joint property, similar to that between spouses. However, the CC brought about a significant change, since it introduced a special system of property acquisition based on the segregation of property as a legal right of de facto partners, which also forced the judiciary to review its previous decisions. Therefore, it can be ascertained nowadays that parties can achieve a common economic goal without actually merging their assets ${ }^{43}$ This is supported by the Curia, ${ }^{44}$ which, in a recent decision, indicated that during cohabitation for 28 years, the parties had separated their property, but made a number of long-term economic decisions that justified the establishment of economic community between them. However, starting a family and having children cannot be considered a common economic goal. ${ }^{45}$

37 CC. $6: 514$. §.

38 Kriston, 2018, p. 5.

39 Hegedús, 2004, pp. 17-20.

40 Pfv. II. 21.089/2011/8. És Pf.17.21.403/2016/3.

41 BDT 2009. 1952.; BDT2007. 1628.; BH 2014.111., BDT2008. 1805. I.

42 BDT 2011. 2601.

43 Kriston, 2018, p. 6.

44 BH 2021.1.11

45 BH2017. 338. 
c) Long-term cohabitation between spouses in a common household. In judicial practice, there was a consensus that parties should live together in a common house in order for a cohabitation relationship to be established between them ${ }^{46}$ However, lasting coexistence does not necessarily mean continuous and uninterrupted coexistence. ${ }^{47}$ Cohabitation in the same real property is not an essential condition for establishing a joint household. Rather, the components of a joint household are cooperation in the choice of a jointly developed way of life, as well as the place and method of cohabitation. ${ }^{48}$ Cohabitation in a joint household, especially between older partners, can take place by the parties retaining their property while sharing it, which means that they can be linked to their way of life as a joint household. ${ }^{49}$

d) Exclusion of the existence of parallel life communities and kinship. The law limits the determinability of cohabitation from a negative angle, as well. The establishment of a partnership is not precluded by the existence of a marriage or registered partnership, but by the fact that the party also maintains the community of life of such marriage or registered partnership. If one party lives in a marital property and life community, it precludes the existence of a cohabitation partnership. ${ }^{50}$ However, the fact that one of the parties maintained a close relationship with another person during the period of partnership does not preclude the establishment of a cohabitation relationship. ${ }^{51}$ Kinship between the parties is an exclusionary factor, just as in the case of spouses, because, as a result of healthy procreation, parties cannot be direct descendants or siblings of each other.

\subsection{Termination of relationships}

\subsubsection{Termination of marriage}

The Family Law Book establishes that a marriage can be terminated by the death of one of the spouses or the dissolution of the marriage by court order. Annulment differs from termination by divorce in that an annulment always has an "ex tunc," effect which is retroactive to the origin. The termination due to death or divorce is valid only from the date of the termination, so it has an "ex nunc" effect. Only the court shall dissolve marriage at the request of either spouse, in the event of the breakdown of a marriage because of irreconcilable differences. Hungarian law does not list the reasons for dissolution, but leaves it to the court to adjudicate circumstances leading to the final estrangement of the spouses. Detailed rules governing dissolution are listed in the Civil Procedure Code. ${ }^{52}$ The Act identifies two forms of dissolution:

46 BDT2016. 3582.

47 BH 2001. 596. 4

48 Hegedús, 2006, p. 13; Kriston, 2018, p. 5.

49 BH 2017.369.

50 BH 2004.504., EBH 2018.M.8.

51 EBH 1782.2008.

52 Chapter XXXI of the Act CXXX of 2016 on Civil Procedure. 
mutual agreement, where the final, mutual, and independent intent of the spouses terminates the marriage and factual dissolution, where detailed evidence is relied on by the court to terminate the marriage. The court examines the evidence and investigates whether the marriage has been completely and irreparably damaged in the case of a factual dissolution. The proceedings may commence in two ways. It may be initiated at the unilateral request of one of the spouses against the other. Alternatively, if both spouses agree to the dissolution, but their conditions for their mutual agreement have not been met, and it is not possible for them to agree on these conditions, they may initiate proceedings. ${ }^{53}$

If the mutual intention of the spouses is based on a final and independent determination, it will be unnecessary to investigate the deterioration of the marriage in detail. In such cases, the court must examine the parties' declarations. Thus, the personal hearing of the parties is important and mandatory during the trial, with exceptions provided by law. In the case of a mutually agreed dissolution, the spouses shall agree on the contributory issues prescribed by law. In the case of a joint minor child, if the spouses agree on joint parental supervision, specifically details regarding the place of residence and maintenance of the child, the maintenance of the spouse on request, and the use of the common house, the marriage can be terminated. If the spouses do not agree on joint parental responsibility, the agreement must identify the scope of exercise of parental responsibility. ${ }^{54}$ If the spouses do not have a joint minor child, they shall only agree on the maintenance of the spouses and the use of a joint apartment, if applicable. The Family Law Book no longer has the previous regulation that called for an agreement on the division of common property as a pre-condition for mutually agreed dissolution. ${ }^{55} \mathrm{~A}$ decision on the dissolution of a marriage can only be made if the agreement of the spouses has been approved by $a$ court order. However, a court will only approve a clear, specific, and enforceable settlement that sets a deadline for the performance of the obligations and that does not contain uncertain and unenforceable conditions. ${ }^{56}$ It is only in the best interests of the joint child to change the provisions of the agreement on the exercise of parental supervision, maintenance of the child or contact, which was approved by a court. ${ }^{57}$

\subsubsection{Termination of registered partnership}

A registered partnership is terminated by the death of one of the registered partners, or by judicial dissolution or termination by a public notary. ${ }^{58}$ According to the Bét. II., the rules on the termination of marriage shall be applied for the

53 Pál, 2016, pp. 22-23.

54 Visontai-Szabó, 2021, p. 8.

55 The reason for this is probably that property relations have become far more complex in recent times.

56 Kőrös 2013, p. 70.

57 CC. $4: 170$. §; 4:181. §; 4:210. §

58 Bét. II. 4. §. 
termination of a registered partnership. In line with this, the Bét. II. identifies two forms of dissolution: factual dissolution, where the parties shall outline the reasons for the termination of the relationship and the mutually agreed dissolution. Instead of the latter, which involves litigation, the parties can choose to terminate their relationship in a non-litigation procedure.

Registered partnerships can be terminated by a public notary if a joint request is made by the registered partners. It is important that the request shall be made without any influence. The public notary who terminates the registered partnership in non-litigious proceedings is entitled to draw up a notarial document. There is no possibility for the termination of a registered partnership by a public notary if any of the partners is legally incapacitated or has limited legal capacity, or the registered partnership can be declared invalid or non-existent. In non-litigious proceedings for the termination of a registered partnership before a public notary, there is no place for proof and certification. An order approving the agreement of the parties has the same effect as an agreement approved by court, and an order terminating a registered partnership has the same effect as a court judgment. ${ }^{59}$

\subsubsection{Termination of de facto cohabitation}

De facto cohabitation ends with the permanent and irreversible termination of life community, which cannot be linked to court or notarial proceedings. Deleting the existence of cohabitation from the Register of Cohabitation Declarations has no constitutive effect, much like registration. Thus, a de facto cohabitation can be found in the register, even if the relationship itself ceases to exist. In such cases, the burden of proof is on the person who claims that the partnership no longer exists, despite registration. The opposite can also happen: that is, a de facto cohabitation relationship may not be found on the cohabitation register, but can still exist.

\section{Personal law relations in the different forms of relationships}

Loyalty is a fundamental component of all three relationships, and is based morality and social customs rather than legal requirements. It is an unenforceable requirement, and covers both sexual relations and all conduct that can harm the interests of the other party. ${ }^{60}$ Accordingly, the requirement of loyalty goes beyond addressing sexual disloyalty alone: it implies a responsible endurance of the relationship

59 See Sections 36/A. § - 36/D. § in the Act XLV of 2008.

60 In the case of marriage, the law states that loyalty is an obligation on part of both spouses. CC 4:24.

$\S(1)$ 
even in difficult times. ${ }^{61}$ Although only spouses are required to cooperate and support each other according to law, ${ }^{62}$ this requirement must be an essential feature of all relationships. ${ }^{63}$ Equality between those living in a partnership extends to all the property and non-property rights of the partners.

The equality of those who living in a partnership covers all the property and non-property rights of them. The obligation of mutual support and solidarity between partners is a multi-layered requirement that calls for the cooperation of the partners. Joint decisions are important for spouses, and registered and de facto partners, and for the settlement of ancillary issues that arise not only during cohabitation, but also during the dissolution of the partnership. The choice of residence is a legal obligation for spouses. ${ }^{64}$ However, partners have to choose their place of residence by mutual consent in a registered partnership and in de facto cohabitation as well. ${ }^{65}$

According to the general rule, the regulations of marriage apply to registered partnerships as well. ${ }^{66}$ Consequently, personal and property relations of registered partners are mostly the same as those of spouses. There are some exceptions and prohibitions that are regulated by the Bét. II.

Among the personal relationships of marriage, registered partnership, and de facto partnership, we can find completely different rules about the persons' name after the establishment of a given partnership.

According to the choice of the parties, wearing a "spouse name" after marriage is not only a right, but also a duty.

While declaring the intention to marry, the spouses may declare the marital name they wish to bear after marriage. Until the marriage is concluded, the declaration can be changed. ${ }^{67}$ According to law, any change of name must be registered in the marriage register and in relevant identity cards and documents. The wife's name choices can be varied for the period after marriage, and both the wife and husband can keep their own names or add the spouse's family name. In the latter case, the spouses have a common marital name. ${ }^{68}$ The declaration of the names of spouses may affect the name of the common child.

61 Behavior that violates marital loyalty is governed by a special rule under family law. BDT2011. 2554.I.

62 CC $4: 24$. § (1)-(2)

63 BH 2013.217.

64 CC. $4: 26 . \S$

65 All European family laws contain a rule on the common choice of home. Resolution No. R(78) 37 of the Committee of the European Ministers addresses this as well. According to this rule, both spouses have an equal right to choose the common home or place of residence for the family that is separate from that of the other spouse. Kőrös, 2013, pp. 78-79.

66 Bét. II. 3. § (1)

67 At. $20 . \S$

68 CC decision No. 58/2001. (XII. 7.) stipulates that men should also be given the opportunity to express their affiliation with their wives through a name change; At. 47. $\S(3)$ This rule was incorporated in the CC as well. CC. 4:27. § (2) 
Registered partners are not subject to the naming rules that apply to spouses. Accordingly, they do not make statements around naming before registration. ${ }^{69}$ There are no rules around naming in the case of de facto partners, either. Consequently, the relationship has no legal effect in this context. However, this does not mean that registered or de facto partners cannot use each other's names in some form. According to Paragraph 49 of the Act on Register Procedure, Hungarian citizens can seek to modify or change their birth or given names, and the office in question can authorize this request. This authorization process is a traditional administrative procedure, in which the parties can ask to bear each other's names.

\section{Property relations in different partnership forms}

\subsection{Property relations in marriage}

\subsubsection{Marital community of property as a legal property regime}

The Family Law Book of the Civil Code regulates matrimonial property in a more detailed and nuanced manner than did the former legislation. The marital community of property is the legal regime governing matrimonial property in Hungary. The law differentiates between property used in the daily life of the spouses and the entrepreneurial assets used by them for their occupation and participation in business. It lays down rules concerning their use, management, and right of disposal, as well as the division of the joint property of the spouses. The Act stipulates special rules on these entrepreneurial assets. There are special provisions that govern a spouse's common house as the family's home.

Based on the principle of voluntary and free choice of the couple, the Family Law Book emphasizes that the spouses shall settle their property relations by way of a matrimonial property contract with content in line with their own intention. ${ }^{70}$

In a matrimonial property contract, current and future spouses can identify the mechanism that would govern their property instead of the statutory property system. This would apply from the date specified in the contract and subsist for the duration of their life community. The Civil Code regulates optional property systems in addition to the legal matrimonial property regime. The legislature did not consider it necessary to provide detailed regulations for a certain property law system in addition to the characteristic provisions of the given system. Those spouses who wish to conclude a matrimonial property contracts will stipulate the content of such contracts in line with their life situations. The law contains provisions for the community 
of acquisition based on the added value principle (the so-called acquisition property) as well as for the property segregation as an alternative systems of property regimes. These provisions protect a spouse from indebtedness and the abuse of rights by the other spouse. A matrimonial property contract can only settle the property relations of the spouses for the duration of their marriage as the term of the contract ceases with the termination of their marriage. However, this does not mean that the parties cannot address the ownership of the assets acquired before cohabitation or the potential division of property.

If the spouses do not conclude a matrimonial property contract, the matrimonial property community is the legal property system. The rules of the matrimonial property regime cover property that are not governed by the spouses' matrimonial property contract. Marital community is a special form of joint ownership. All property, property values, rights, claims, and debts that the spouses acquire together or separately during the existence of marital cohabitation and that are not the separate property of either of them, ${ }^{71}$ and shall be encumbered indivisibly from the date of acquisition or claim. Recent judicial practice has also clearly emphasized that the property within the scope of matrimonial property law is broader than property in the general sense.

The spouses' property can be divided into legally separable sub-properties from the date of acquisition: for the separate property of the spouses and for the joint property. This system does not mean the total aggregation of assets, as the spouses' assets at the beginning of and during the marriage (e.g., gift, inheritance) or from the source remain separate. The following "assets" constitute the active side of common property: ${ }^{72}$ things, money and securities, and property rights ${ }^{73}$ such as a usufruct, utilization, rental right, praxis right, etc., and claims. ${ }^{74}$ Common property also has a passive side: burdens of assets of common property, common debts, or interests of common debts. Common property covers debts arising from a contract concluded toward meeting expenses pertaining to such common property. A loan taken out by one of the spouses is joint debt even if it has been used to purchase property belonging to the community property or to promote joint economic activity. Tax, health insurance, pension, and employee contribution tax on the income from the earning activity of the spouses constitute common debt, because the income from the earning activity during cohabitation is also common. ${ }^{75}$ The joint acquisition of the spouses refers to an equal acquisition, so it is presumed that the acquired property falls within the joint ownership of the spouses. However, contrary to the presumption of an equal acquisition, it can be proved that the acquisition ratio differs as a result of a separate investment or expense. According to this rule, the spouse has a claim in rem on half

71 CC. $4: 37 . \S(4)$

72 CC. $8: 1$. § (1) 5 .

73 BDT2016. 3472. I., BDT2012. 2754., BDT2001. 542., ЕВH1999.23., ВН2000. 395., EBH 2002. 658., BDT2005. 1124. I.

74 CC. $5: 14$. $\S(1)-(2)$.

75 BDT2012. 2754. II., BH1998. 233., BH2013. 154. 
the property acquired by either of the spouses and has a contractual settlement claim on half the value of the property rights or claims belonging to the joint property. However, (s)he is also obliged to bear the share of joint obligations. The "indivisibility" of property emerges from the fact that during the existence of the community of property, the spouses cannot dispose with their shares independently. From this point of view, the marital community is a closer link than the general civil law common property, where the owners have the right to dispose of their own shares, within the framework of certain restrictions. ${ }^{76}$ The two most important elements of the entry into force of a matrimonial property partnership are the establishment and existence of a marital bond and marital life community. The statutory property regime applies from the beginning of the cohabitation if the spouses lived together as cohabitants before marriage. The formation of a life community shall be presumed by the conclusion of the marriage. ${ }^{77}$ If the parties merely concluded a marriage but did not enter marital life community with each other, matrimonial property will not be established. If the parties enter into marriage without the intention of cohabitation and life community, it becomes a fictional marriage that does not create a property community between the parties.

The conceptual elements of life community cannot be found in law because it has been developed by judicial practice. The characteristics of the marital life community include economic, family, and personal aspects. Economic characteristics involve running a common household, joint farming, and cooperation to achieve different economic goals. Family facts include characteristics of belonging together, such as cohabitation in a shared dwelling, continuation of a regular sex life, joint care and upbringing of the child(ren), other relatives, and themselves, either within the framework of a common household or in any other way, or the existence of an internal, personal, and responsible perseverance (solidarity). If one of the parties lives in a marital life and property community, this precludes the existence of a partnership of cohabitation. ${ }^{78}$ However, the Supreme Court has emphasized that the existence of cohabitation is not precluded if one of the parties have a marital bond with another party. The establishment and existence of a de facto cohabitation is not precluded by the fact of a marital or registered partnership, but by the existence of $a$ connecting life community. ${ }^{79}$

\subsubsection{The right to use the dwelling and spousal maintenance}

The property relations of spouses also incorporate the provisions for the settlement of the right to use the dwelling of former spouses. The development of special rules for the use, availability, and settlement of spousal housing was necessitated by 
the fact that in most cases, the spouses' joint residence is the home of the family, which is also the scene of family life and raising children. Therefore in line with foreign examples, the law protects the right of spouses and their children to use the dwelling, regardless of which of them owns or rents the dwelling as an "asset".

The Civil Code provides for several types of settlement so that divorced spouses are not forced to live together, and seeks to encourage spouses to settle their dwelling use by sharing the joint property, if possible. ${ }^{80}$ However, in the case of settlements, it is always a fundamental aspect to investigate which spouse will exercise parental custody over the joint minor children in the future, and about that it is exclusive or joint custody. ${ }^{81}$

Spousal maintenance is a family law institution that characterizes both the personal and property relations between spouses. It arises from the basic institutional nature of marriage that the spouses' liability toward each other does not cease completely after divorce. Therefore, one is obliged to provide financial care for the former spouse if (s)he needs maintenance. The maintenance claim and obligation of the spouses are mutual: both the (ex) husband and the (ex) wife are entitled to and liable for it. The basis of maintenance is a valid marriage.

According to the Hungarian legal literature, spousal maintenance obligation has three stages. ${ }^{82}$

The first stage involves providing support in the course of marital life, where the spouses shall not only help each other in spiritual and sensual ways, ${ }^{83}$ but also in economic ways. The second stage starts with the termination of life community and ends with the dissolution of marriage. The third stage comprises providing maintenance for the ex-spouse after such dissolution. The Civil Code links the second and third stages by granting the same subjective right of maintenance for both the separated spouse in need and the former spouse. The duration of the marriage is irrelevant for maintenance claims. However, if the life community-and not the marriage community-lasted for less than a year, and no child was born out of the marriage, the former spouse is entitled to maintenance for the duration of the life community. In special cases, the court may order the provision of maintenance for a longer period. ${ }^{84}$ The ideological basis is that marriage is considered a long-lasting life community by the legislature and society. Thus, short cohabitation cannot result in all legal effects that a long-lasting marriage can produce.

The conditions for spousal maintenance are as follows: if the spouse is unable to support himself/herself for reasons beyond his/her control and the lack of undeserving the maintenance on the side of the entitled party and the ability to provide maintenance on the side of the obliged party. The Civil Code has limited

80 Justification under the Civil Code.

81 See in detail: CC 4:76. §-4:85. §.

82 Lábady, 2014, pp. 30.

83 CC. $4: 24$. §.

84 CC. $4: 29$. $§(3)$. 
the enforcement of a maintenance claim to five years from the date of termination of life community, indicating that if the need arises five years after the dissolution of cohabitation, maintenance may be provided only in exceptional circumstances. Therefore, the date on which the former spouse's need arises is important: if the need occurred within five years of the termination of life community, and not after the dissolution of marriage, the maintenance can be claimed later, even after five years from separation. For example, the long-time re-establishment of life community after the dissolution of marriage can be an exceptional circumstance.

\subsubsection{The spouses' right to intestate succession}

The condition for the intestate inheritance of a surviving spouse is a valid marriage and the existence of life community with the successor and his/her spouse at the time of succession. ${ }^{85}$ In the absence of a spouse, his/her descendants do not have a right of inheritance. A widow is entitled to half the matrimonial property in line with the rules provided by the matrimonial property regime, and not as an inheritance. Therefore, only the other half of the spouses' common or separate property belongs to the testator's estate, which does not qualify as lineal property. ${ }^{86}$ The CC. divides the property into two parts: the family dwelling, which is used together with the testator, including furnishings and appliances, and the rest of the property. The widow inherits life-long usufruct on the dwelling and inherits one share property which is equivalent with the share of a child from the property under the second category. With this, the surviving spouse can use the family dwelling. The law does not provide a subjective right to the descendants to restrict the usufruct right of the widow. In the rest of the estate, such as cash, shares, bank deposits, stocks, cars, and other real estate, the law creates a joint property between the surviving spouse and the children of the successor in such a way that the widow owns one share which is equivalent with the share of a child from the property with the children. This situation can create serious conflicts when the successor's widow and her children, and children from a previous marriage (relationship), are forced to resolve disputes over joint ownership or to terminate the joint ownership entirely. If there is no descendant, the successor's spouse inherits the property together with the parents of the successor. The CC. divides the estate into two, namely the family dwelling that is used together with the successor-if it is not the subject of lineal succession-including furnishings and appliances, and other property. The property named in the first category is succeeded by the spouse of the successor, as the law intends to protect the former life circumstances of the widow even if there are no children. In the second category,

85 CC. $7: 62 . \S$.

86 The purpose of lineal succession is to ensure that property in the estate of the successor who has died without a will and without children and acquired that property from their ascending relatives free of charge should flow back to the branch from which it originated and not to the spouse that did nothing toward acquiring it. CC. 7:67. §-7:71. §. 
half the estate is inherited by the successor's spouse, and the other half by the testator's parents in equal shares, so that the parents inherit in $1 / 4-1 / 4$ proportion. ${ }^{87}$ If a parent is debarred from succession, the other parent and the successor's spouse shall succeed in equal measure. If there is no descendant or parent, or if they are excluded from succession, the surviving spouse shall receive the entire estate. In this case, only the rules on lineal succession can restrict the sole succession of the spouse.

\subsection{Property relations of registered partners}

According to Section 3. (1) of the Bét. II., the rules on marriage shall apply to registered partners as well, with the exceptions laid down in the Act. Therefore, registered partners are entitled to the same rights and obligations in personal and property relations as are spouses. Consequently, all the above mentioned rules concerning the matrimonial property regime, the right to dwelling, and intestate succession shall apply to registered partners as well. ${ }^{88}$

\subsection{Property relations of de facto partners}

\subsubsection{The legal property regime of de facto cohabitants}

The property law regulations of de facto partners-similar to the concept of cohabitation-are defined under the Obligation Law Book of the Civil Code. The CC. aims to guarantee the private autonomy of the parties and consequently strives to settle property issues primarily within the framework of a cohabitation property contract, which can be concluded both before and during the establishment of the cohabitation relationship and lasts until the end of such cohabitation. The rules concerning matrimonial property contracts apply to the content, amendment, and termination of cohabitation property contracts. ${ }^{89}$

If the parties do not wish to enter into a property contract with each other, they are subject to the provisions of the legal property regime. The Civil Code of 1959 indicated that the spouses would acquire joint ownership in proportion to their involvement during their cohabitation. ${ }^{90}$ There was also a uniform judicial practice in that the presumption of joint acquisition prevailed in respect of an increase in wealth that occurred during the tenure of the cohabitation..$^{91}$ However, the equal acquisition of cohabitants was not a presumption, but only a supplementary rule that could apply if the real cost of acquisition could not be established after an evidence procedure. The Civil Code of 2013 placed the legal property system of cohabitants on new ground,

87 CC. $7: 60$. §.

88 Kőrös, Kőrös 2013a, p. 7.

89 Kriston, 2014, pp. 35-40.

90 Szeibert, 2012, pp. 173-189.

91 BH1996. 258., BH2007. 122. Hegedús, 2008, pp. 11-19. 
wherein cohabitants began to be considered independent in their property acquisitions during their relationship, but after the termination of the relationship, either party can demand a share in the growth in assets. Assets constituting separate property of a given partner shall not be considered a part of the growth in assets (e.g., property existing at the time of the establishment of the partnership; property inherited or gifted by the spouse during the life of the cohabitation, and/or free benefit). While dividing the growth in assets, the governing principle is the acquisition of property. Thus, partners are entitled to a share in the jointly acquired property primarily in kind, in proportion to their contribution. Determining the proportion of participation is left to the courts to handle. This creates serious difficulties around proof in practice. According to equity and the need to protect the weaker party, the work done in the household and child-rearing, and in the other partner's enterprise shall be construed as a contribution toward acquisition. If the ratio of contribution cannot be determined, it shall be considered equal, unless this would constitute an inequitable financial loss in respect of either partner. The legal property system between cohabitants can be considered specific, however, it bears many similarities with the property acquisition regime that can be concluded between spouses by contract. ${ }^{92}$

\subsubsection{The right to use the dwelling and maintenance}

The property relations cover the provision of the right to use the dwelling, which is called the legal effect of the de facto cohabitation relationship. ${ }^{93}$ The development of special rules in this area was necessary because in most cases the joint house of the cohabitants also refers to the home of the family, which is an important component of family life and the upbringing of children. Therefore, in the event of the termination of a de facto cohabitation, the legal provisions on the use of a dwelling can only be applied if such a cohabitation has lasted for at least one year and at least one child has been born from this relationship. Otherwise, the rules of the law governing the use of a dwelling shall not apply to separate cohabitants.

The principle of the best interests of the child also has paramount importance in resolving issues concerning the dwelling, because the joint minor child's right to use the house should be taken into account. ${ }^{94}$ The Supreme Court stated that dwelling issues of cohabitants are covered by independent principles of family law, namely the principles of equity and the protection of the weaker party. ${ }^{95}$ Another key impact of a cohabitation relationship is that either partner is entitled to demand maintenance from the other if they are unable to support themselves for reasons beyond their control if their civil partnership existed for at least one year and a child was born from it. The conditions for the maintenance of a cohabitant are the same as those for

92 CC. $4: 71 . \S(1)$.

93 CC. $4: 92$. §-4:95. §.

94 Szeibert, 2013, pp. 147-158.

95 BH2021. 11. 
the maintenance of a former spouse, namely the needs of the party, the absence of fault, the lack of unworthiness, and the capacity on the obligatory side. The former partner can claim maintenance for one year from the end of cohabitation. If the former partner is in need of support after one year following the termination of the civil partnership, maintenance may be provided in exceptional cases. The excohabitant is entitled to maintenance just as a separated spouse and ex-spouse are. However, the cohabitant is not obliged to support his or her former partner if doing so would jeopardize the maintenance of their children or themselves. The common rules of maintenance (for example, the amount, its performance, etc.) will apply. However, the right to maintenance ceases if the entitled partner establishes a new de facto cohabitation or registered partnership or marriage. De facto partners do not have an intestate right to inherit. They can only inherit after each other if they make a will to such effect.

\section{Legally recognized forms of the establishment of descendant family relationships}

Part Four of the Family Law Book of the Civil Code addresses the establishment and termination of kinship and its legal consequences, such as parental responsibility, custody, and child support. It includes family relationships established by adoption, as adoption provides the adopted child with full family status in the family of the adopter. In addition to the biological fact of descent and the adoption based on an act of public authority, there are also the so-called actual family relationships, such as the family relationship between the stepparent and the stepchild, foster parent and foster child, or the child's placement with a family. These relationships are closely aligned with the law governing kinship. Although the Civil Code does not define the concept of "kinship," it mentions two equivalent institutions of kinship, namely blood descent and adoption in connection with the kinship relationship in a direct line. The Civil Code states that an adoptee receives legal status as the adoptive parent's child.${ }^{96}$ From the perspective of the child, therefore, no distinction can be made on the mode of descent-that is, by blood or adoption. A child cannot be discriminated against based on how the parental status was established, that is, whether he/she was born out of marriage, cohabitation, or occasional sexual intercourse, or whether he/she was raised and cared for by blood or adoptive parents. This applies to the family law consequences of the parent-child relationship, and to all other legal effects (for example, the child is the legal heir not only of the man declared to be his father, but also of the relatives of his father). However, we should be aware that the Basic Law of Hungary does not recognize de facto cohabitation relationships as 
families deserving of constitutional protection. As a result of the dual regulation of the Civil Code, persons in de facto cohabitation relationships have far fewer rights both during and after the cohabitation relationship as spouses. This fact-not directly but indirectly-affects children born out of a de facto cohabitation.

Kinship based on descent is established by legal facts specified by law, such as marriage, a reproduction procedure, and an acknowledgment of paternity, which do not necessarily coincide with the biological fact of descent. Kinship based on descent as "legal parentage" is primarily based on presumptions. However, the law must seek to bring legal facts and circumstances underlying a relationship in direct line-that is, maternity or paternity_ "as closely as possible to the real biological descent." However, the legal relationship between the parent and child can be established not by biological origin but by a form recognized by law. Therefore, for example, the presumption of paternity based on marriage may be established between a father and child who are otherwise not in a blood relationship.

\subsection{Paternal presumptions}

The importance of the family status of a child can be expressed in the interest of a normal family life. The orderliness of the family status of a child provides a basis for the child to live in a legally recognized family relationship, which can be regarded as legally complete if both paternal and maternal status are occupied in the child-parent relationship. From a social standpoint, however, it is only considered complete if the people who gave birth to the child are established as the father and mother of the child and are registered in the birth register. ${ }^{97}$ The CC. lists the legal facts generating paternity in the order in which they are applied:

- the marriage bond of the mother,

- special procedures for the purpose of human reproduction in the case of de facto partners,

- the acknowledgment of paternity,

- the determination of paternity by court decision.

If paternity is established by a presumption that is higher up in the order presented above, subsequent presumptions cannot be applied. ${ }^{98}$ It is an exception under the general rule, so if the presumed time of conception-i.e. 300 days-did not lapse between the time when the mother's previous marriage was terminated and the date when the child was born from a human reproduction procedure. In this case, it is not the spouse in the first place, but the de facto partner of the mother who is considered the child's father. The same situation arises if after successful reproduction between de facto cohabitants, the mother enters into marriage with another man before the birth of the child. This marriage also does not invoke the presumption of paternity in 
respect of her husband.$^{99}$ The system of presumptions of paternity remains uniform, that is, they have the same legal consequences regardless of whether the child was born in or out of wedlock.

a) Presumption of paternity based on marriage. The presumption of paternity based on marriage is established automatically. The man with whom the mother lived in wedlock from the alleged time of conception of the child until the birth of the child - that is, 300 days before the birth of the child—or at least during a part of this period, shall be considered the father of the child. ${ }^{100}$ For the presumption of paternity based on marriage, the conclusion of the marriage has legal effect. It does not matter whether the spouses actually lived together or whether the mother had sexual contact with her husband alone. Therefore, the husband of the mother is the father of the child even if the mother is already living with another man-without terminating her previous marriage-and the child did in fact originate from the mother's sexual contact with such other man. The ipso jure establishment of the paternity of the already "abandoned" husband puts the biological father in a difficult position, as the paternal status is occupied. This forms a legal obstacle to the acknowledgment of his paternity. However, the CC allows a joint request to be made by the presumed father, the mother, and the man who wishes to make a fully enforceable acknowledgment of paternity to declare that he is the father of the child; upon receiving this, the court shall establish, in non-contentious proceedings, that the father of the child is not the mother's husband or former husband. ${ }^{101}$ The CC. allows a court, in a non-litigious proceeding, to declare, at the joint request of a presumed father, a mother, and a man seeking full recognition of a child through paternal acknowledgment, that the child was not born from the mother's husband or ex-husband's father. However, the issue of paternity must be settled in the same procedure by a full-fledged paternity declaration. In the same action, paternity shall be established by means of a fully enforceable acknowledgment. ${ }^{102}$ The law solves the problem of conflicting presumptions of paternity based on two marriages between the presumed conception date and birth of the child. The presumption of paternity is linked only to the newer marriage. Based on a previous valid or invalid marriage, only an underlying presumption of paternity can be established. If the presumption of paternity against the new husband is rebutted, the presumption of paternity of the former husband will be resurrected.

b) Presumption of paternity based on a special procedure for the sake of reproduction. A special procedure for reproduction ("reproduction procedure") can be carried out by persons living in marriage or by a heterosexual couple living in a de facto cohabitation, if it is unlikely for a child to be conceived in a natural way from the relationship because of the infertility of either party. According to the law, the

99 CC. $4: 100 . \S(2)-(3)$.

100 CC. 4:99. §.

101 Kun, 2018, pp. 38-40.

102 CC. 4:114. §. 
reproduction procedure can only be carried out at the joint request of the de facto partner in a private document containing conclusive evidence, based on which the applicants accept that the family status of their child born this way is exactly the same as that of a biological child. ${ }^{103}$ However, in the case of de facto cohabitation, a reproduction procedure may be carried out only if none of the de facto cohabitants has a marital relationship. The reason for this is that the paternal status in case of a child born from a reproduction procedure between spouses is based on the marriage of the mother; therefore, such a procedure creates paternal status only in case of de facto partners. Thus, Act CLIV of 1997 on Healthcare (Healthcare Act) emphasizes that neither de facto partner can have a marital relationship during the reproduction procedure. ${ }^{104}$ However, the marriage of the parties may be terminated after the fertilization of the female gamete during the reproductive process, for example, with the death of the husband. An embryo that came into existence outside the body is entitled to the status of a fetus from the date of implantation. ${ }^{105}$ The determination of paternal status in such cases is not always clear.

In sum, the reproductive process gives rise to a presumption of paternity only if the applicants are unmarried partners of different sex, none of the applicants are married, the male member between the partners is involved in the reproductive process, and the child's origin is a consequence of the reproductive process. ${ }^{106} \mathrm{~A}$ single woman can undergo a reproductive process if, because of her age or health (infertility), it is unlikely for her to have a child naturally. ${ }^{107}$

c) Presumption of paternity based on the acknowledgment of paternity. If the mother was not married between the point of conception and the date of birth of the child and did not participate in a reproduction procedure invoking the presumption of paternity, or if the presumption of paternity was invoked and rebutted, the man who admitted in a fully enforceable acknowledgment of paternity that he is the father of the child shall be considered the father. An acknowledgment of paternity can be made from the point of conception by a man who is at least 16 years older than the child. An acknowledgment of paternity shall be construed fully enforceable with the consent of the mother, the child's legal representative, and the child, if he/she is over the age of 14 years. The acknowledgment and consent shall be executed in a statement made before the registrar, court, guardian authority or shall be executed in a notarial document. ${ }^{108}$ Once the statement is signed, the acknowledgment of paternity cannot be withdrawn. ${ }^{109}$ 
d) Presumption of paternity based on a court decision. The law considers the judicial determination of paternity an irrebuttable presumption. It rejects the possibility that, after the court has "thoroughly considered all the circumstances" to infer paternity, another lawsuit could be filed to prove that it is "impossible" for the child to originate from the presumed father. Paternity may be established through a judicial process, if a child's father cannot be identified based on the mother's marriage, reproduction procedure, or fully enforceable acknowledgment of paternity. The judicial determination of paternity is not possible in the case of a donor providing a gamete or embryo if the mother became pregnant through a reproductive procedure.

In practice, the presumption of paternity is established by a court decision when it is necessary to determine the paternity of a man who has conceived the child but he does not wish to undertake paternity, or when the mother opposes the settlement of paternal status for some reason and does not consent to the fully enforceable acknowledgment of the paternity of the father. The establishment of the presumption of paternity by a court can also occur where the age difference is less than 16 years between the child and the man asserting paternity, which is a condition for the acknowledgment of paternity. In the event of the legal incapacity of the father, there is no possibility of acknowledging or establishing paternity in any other way. The establishment of the presumption of paternity by a court requires double proof: it must be proven that the man had engaged in sexual intercourse with the mother at the time of conception and, upon careful consideration of all circumstances (based on physiological tests), there are reasonable grounds to consider that the child was conceived as a result of such sexual contact. ${ }^{110}$

The law continues to provide the opportunity for a man interested in a lawsuit to recognize the child with a fully enforceable acknowledgment of paternity during the paternity suit. ${ }^{111}$ He must be warned of this in the first hearing and after the evidentiary procedure has taken place. In paternity and other lawsuits that aim to determine the origins of a child, there is a significant individual and social interest that the child can obtain from a legal parent-child relationship with the biological father. Judicial practice places great emphasis on the fact that the establishment of origin (paternity) is based on duly substantiated facts and the results of scientific studies. ${ }^{112}$

\subsection{The fact of maternity}

For a long time, maternal status was not the subject of debate: the law treated motherhood-going back to Roman law ("mater semper certa est")—as a fact and not as a presumption. However, the parental status and biological origin of the child has been revalued since genetic and foster motherhood (parenthood) have been

110 CC. $4: 103 . \S$.

111 Civil Procedure Act 468. §.

112 Mécsné, 2000, pp. 425-429. 
separated in several cases during reproductive procedures, such as where donor gametes or donated embryos are used. ${ }^{113}$ The Civil Code chooses between the biological and genetic mothers in accordance with international practice and considers the woman who gave birth the mother. This new rule is important not only from the standpoint of reproductive procedures that are permitted under current law, but also crucial from the standpoint of surrogacy (nursing pregnancy), because, as a result of that provision, a woman who has asked another woman to carry an embryo derived from her ovum cannot be considered the mother. ${ }^{114}$ In Hungary, neither surrogacy nor nurse pregnancy is allowed.

Although the Civil Code does not regulate the recognition of maternity, it may be appropriate in case of the "emptiness" of maternal status (for example, if the mother of an exposed or found child demands the child) if the mother demands the child within six weeks and can prove beyond doubt that she is the real, biological mother of the child. If the identity of the mother of the child is in dispute or cannot be established, this question can only be clarified in a maternity lawsuit in keeping with the Civil Code. The claim seeks to award maternity status to the person so designated. This request can be issued on two grounds: one, if the maternity position is vacant (for example, the mother demands that a child be placed in an incubator or be found) and, the other, where the plaintiff seeks to establish that a person shown in the registry of births as the mother is not the one who gave birth to the child (action for a negative declaration) and that the mother is the person he/she designates (action for a positive declaration) thus. In the event of erroneous registration (for example, the mother was registered based on a stolen identity card or the children were exchanged at the hospital), the Civil Code considers maternity lawsuits secondary means, because the parties should first try to remedy the wrong entry through an administrative procedure. A lawsuit can be initiated only if this fails. ${ }^{115}$

\subsection{Descendant relationship through adoption}

The legal sources on adoption are very diverse. ${ }^{116}$ Under the Civil Code, the main purpose of adoption is to ensure that minors grow up in a family when their biological parents are unable to help them do so. Adoption refers to the admission of a person outside the family as a full member of the family. The purpose of adoption differs in spousal and kinship contexts, and in other contexts, where a child is adopted by a person outside the family. ${ }^{117}$ The Civil Code states that "family relationship in direct

113 Herczog, 2020, p. 46.

114 Navratyil, 2012. pp. 142-145; Szabó-Tasi, 2012, p. 14.

115 Barzó, 2017, pp. 318-321.

116 In addition to the Family Law Book of the Civil Code, the Succession Law Book also contains the inheritance effects of adoption. The Act on the Protection of Children (Act XXXI of 1997. Gyvt.), and partly the Guardianship Order (149/1997. (IX. 10.) Order) also contains regulations.

117 Katonáné Pehr, 2007, pp. 447-450. 
line between parent and child is established by descent or by way of adoption. A child shall be related to all his/her parent's relatives upon descent or adoption."118

Adoption has two main objectives: to establish a family and kinship relationships between the adopter(s) and their relatives, and between the adoptee and their descendants; and to ensure that a minor is raised in a family where the proper development of his/her physical, moral and intellect is ensured. ${ }^{119}$ For adoption, identical petitions should be submitted by both a person who wishes to assume the parenting responsibility of a child and that child's legal representative, together with the consent of the child's parents and the spouse of the adoptive parent. A minor of limited legal capacity over the age of 14 years may be adopted only with his/her consent. A minor of sound mind under the age of 14 years shall be heard and his/ her opinion shall be taken into consideration wherever appropriate. In the adoption process, efforts should be made to ensure a degree of continuity in the child's upbringing, with particular regard for his/her family ties, nationality, religion, mother tongue, and cultural background. In Hungary, adoption shall be authorized by the guardian if the legal requirements are met and if it is deemed to be in the child's best interests. ${ }^{120}$ As a general rule a child may only be adopted by a married couple, except where the child is adopted by a relative or the parent's spouse. ${ }^{121}$ Registered partners and de facto cohabitants cannot adopt children. Consequently, the joint adoption of a child by same-sex partners is not allowed. This change entered into force March 1, 2021 onward. Based on the previous regulation, joint adoption was possible only for spouses, but the mode of adoption was essentially the same for spouses and single adopters. Single adoption resulted in the same legal consequence as when only one parent of a child was related by descent. The Civil Code previously established the priority of adoption by spouses. However, this clause was overwritten by an amendment with the legislative justification that a child should only be adopted by married couples so that the child could be raised in a family. An adoptive parent must be at least 25 years of age with legal capacity at the time of adoption, and must be the child's senior by at least 16 to 45 years; further, a person is considered suitable to adopt a child based on his/her personality and other circumstances. ${ }^{122}$ Where an application for the adoption of a child over three years of age is submitted, in the best interests of the child, adoption may be authorized even if the age difference between the adoptive parent and the child is no more than 50 years. In the case of adoption by a relative or spouse, the age difference requirement does not apply. In the case of adoption as a common child, the age and age difference requirement set out in the law shall be satisfied by either of the adoptive parents. If the adoptees are siblings, the age of the older child shall be taken into consideration. Any person 
whose parental supervision has been terminated by court order, or who has been excluded from public affairs, and whose child is under foster care may not adopt a child. In cases of exceptional circumstances specified by law, suitability for adoption of a person wishing to assume the parenting of a child alone may be established in accordance with a relevant government decree, by completing the procedure defined therein. ${ }^{123}$ At present, however, it is not possible to know how the exception will work in practice.

\section{Legal framework of the parent-child relationship}

Minor children are under parental custody or guardianship. ${ }^{124}$ It clearly follows from this fact that it is legally impossible for a child not to have a parent with parental custody or a guardian. In the case of a child born within a marriage, parental custody is established in both the paternal and maternal positions by birth, that is, "ipso jure" by virtue of law. Apart from the exceptional rules on adoption, parental custody cannot be waived or resigned, and parental custody of a minor child can only be terminated in cases specified by law and by court. The rights and obligations arising out of parental custody under the law are as follows: naming the child, care, training and instruction of the child, selecting the home and residence of the child, management of the assets of the child, legal representation of the child, right to nominate a guardian, and the right to be excluded from guardianship. In addition to parental custody, the Family Protection Act ${ }^{125}$ defines the rights and obligations of the parent as follows. The mother and father have the same obligations and rights based on parental custody. A parent is obliged and entitled to take care of his or her minor child in the family, in order to bring him/her up responsibly, and to ensure the conditions necessary for his/her physical, mental, spiritual, and moral development and access to education and healthcare. It is the duty of the parent of a minor child in particular

- to respect the human dignity of the child,

- to cooperate with the child,

- to inform the child of issues concerning him/her-according to his/her age and development and to take his/her opinion into account,

- to provide guidance, advice, and assistance for the exercise of the child's rights,

- to take necessary measures to enforce the rights of the child, 
- to cooperate with persons and bodies involved in the care of the child and with the authorities,

- to take care of the child in accordance with the provisions of a separate law when the child is in a public place or club at night.

Act LXXIX of 2021, which was enacted in June 2021, contains several child protection rules in addition to stricter action against pedophile offenders. According to the Act, pornography and content that depicts sexuality self-centered, or promotes deviation from birth gender identity, gender reassignment, and homosexuality is prohibited to be available to anyone under the age of eighteen. ${ }^{126}$ Anyone under the age of 18 years cannot be made available for any advertisement that depicts sexuality self-centered, or that promotes deviation from the gender identity assigned at birth gender identity, gender reassignment, and homosexuality. ${ }^{127}$ With the amendment of the National Public Education Act, school sessions on sexual culture, life, sexual orientation and sexual development for students should not aim at the deviation from birth gender identity, gender reassignment, and homosexuality. ${ }^{128} \mathrm{~A}$ person or organization other than the employee of the educational institution, in a teaching position, and the school health service specialist in the institution, and state body with a cooperation agreement concluded with the institution, can conduct a school session on sexual development, the harmful effects of drug use, the dangers of the Internet, and other physical and mental health improvements only within the limits set by law. ${ }^{129}$

A parent is obliged to use the support received for the child, toward caring for and raising the child. They are obliged to maintain the child in a manner specified by law, with the exceptions specified by law applicable; and they are obliged to maintain a minor child even by limiting their own maintenance. ${ }^{130}$ The Civil Code determines the principles governing the exercise of custody rights by parents, which is decisive for the parent-child relationship, with due respect for the priority of the best interests of the minor.

In the context of parental custody, cooperation between parents is essential to promote the proper physical, mental, and moral development of the child, regardless of whether the parents live together or separately. However, the obligation to cooperate does not always and in all respects constitute a right of consent or joint decision if only one parent exercises parental custody of the joint minor child(ren) after the separation of the parents. In such cases, the parent living separate and apart shall exercise the joint right of decision only in respect of the major issues

126 Section 3/A.§ and 6/A.§ of the Act XXXI of 1997 on the protection of children and the guardianship administration.

127 Section 8 (1a) of the Act XLVII of 2008 on the basic requirements and limits of economic advertisement; Section 5/A.§ of the Act CCXI of 2011 on the protection of families.

128 Section 9 (12) of the Act CXC of 2011 on the National Public Education Act.

129 Section 9/A of the Act CXC of 2011 on the National Public Education Act.

130 Csvt. 9-10. §. 
pertaining to the child's well-being. ${ }^{131}$ In other contexts, the parent raising the child is only obliged to inform the separated parent of the child's development, state of health, and education. ${ }^{132}$ The Civil Code also enables the court to delegate certain rights to the parent living separately and apart from the child in connection with caring for and raising the child. In such cases, the parent authorized by the court exercises exclusive parental custody; however, the parent living separately and apart shall inform the parent having the right of custody of such activities. ${ }^{133}$ The Civil Code emphasizes the cooperation obligation of the parent having the right of custody and the parent living separately and apart from the child in the interest of the child's balanced development, with due respect for and without any disturbance to the family life of each other. ${ }^{134}$

As part of parenting responsibilities, the parent must educate the minor child with general moral norms and shape the minor's character, values, and habits in accordance with the moral requirements accepted by society. Respect for life and human dignity is the central element of moral education and the core of socialization and emotional intelligence of a minor child. These aspects are violated if the caretaker of the minor does not do his or her best to teach the minor these values, and thus fails to shape the child's emotional stability, and mental balance and health. The caretaker is responsible for the imputable failure to comply with these obligations. ${ }^{135}$

One of the most important principles in family law is the equality of spouses. ${ }^{136}$ However, the legislature also considered it important to place special emphasis on the requirement of equality with respect to the parents. Another important principle in the exercise of parental custody is the involvement of a child in matters affecting him or her. The parents shall inform their child concerning all decisions that pertain to the child, and shall permit the child of sound mind to express his/her views before a decision is made, and to partake in making the decision together with his/ her parents in cases defined by law. The parents shall take the child's opinion into account, giving due weight, consistent with the child's age and degree of maturity. ${ }^{137}$ The Civil Code also obliges the court to hear both parents during the proceedingsexcept where unavoidable impediments exist-and to inform the child of sound mind of the possibility of making a statement. If the child requests to be heard or if the court considers it justified in the absence of an explicit request from the child, the court

131 Major issues pertaining to the child's well-being can include naming a minor child and changing the child's name, relocation of the child's residence to a place other than one where his/her parents live or abroad for long-term residence or for the purpose of settlement, changing the child's citizenship, and decisions relating to the schooling or career path of the child. CC 4:175. §.

132 CC 4:174. §.

133 CC $4: 176$..

134 CC $4: 173$. §.

135 BDT2010. 2364.

136 CC $4: 3$. §.

137 CC 4:148. §. See also: Darnót, 2017, p. 24; Gyengéné, 2018, pp. 2-9. 
shall hear the child directly or through an expert. If the child is aged over 14 years, the decision relating to custody and his/her placement can be made upon the child's agreement, except ${ }^{138}$ when the child's choice is considered to jeopardize his/her development. ${ }^{139}$ In addition to the principles for the exercise of parental custody, the Civil Code regulates, in several places, respect for the views of the minor of sound mind. ${ }^{140}$

However, the assessment of whether a child has sound mind is extremely complex. Can it be linked to a specific age, and if not, is there, for example, a psychological method by which the presence or absence of sound mind can be determined? According to the legal source (Gyer.) ${ }^{141}$, a child of sound mind is a minor who, in accordance with his or her age, intellectual and emotional development, can understand the essential content and see the expected consequences of the facts and decisions concerning him or her. ${ }^{142}$ Despite this definition, it is a serious problem in practice to assess the sound mind of a child involved in the proceedings, which is often not available to the court or guardian authority. Based on the analysis of specific court and guardian authority cases, it can be seen that in almost all cases, the court hears a child over the age of 14 years with binding force, and in all other cases, it entrusts this task to a specialist, that is, a forensic psychologist. ${ }^{143}$ Even without psychological knowledge, it is obvious that there are issues on which a minor before the age of 14 years-even at the age of 6 or 7 years-can give a meaningful opinion, and there are also issues on which even an elder minor cannot be considered competent. ${ }^{144}$ Children can usually be heard in court proceedings with respect to parental custody from the age of 3 years onward, or sometimes even before that, depending on their intellectual development. According to established judicial practice, they are optimally heard with the involvement of a psychologist until the age of about 10 years..$^{145}$

The exercise of parental custody may be restricted or revoked by a court or other authority only in exceptional cases specified by law, and only to the extent strictly necessary to safeguard the best interests of the child(ren). However, the restriction on parental custody used for the protection of child(ren) must always be proportionate to the seriousness of the emergency or the harm proven. However, in practice, the assessment of the degree of vulnerability poses a serious dilemma in all cases. ${ }^{146}$

138 The text of the Act LXII. of 2021 with effect from 1 August 2021.

139 CC $4: 171$. § (4).

140 BH2019. 298., CC 2:14. § (3); CC 4:120. § (2); CC 4:181. § (1)-(2); CC 4:228. §

141 Government Decree 149/1997. (IX. 10.) on the guardianship authorities, child protection and guardianship procedure.

142 Gyer. 2. § a); Ádámkó, 2015, pp. 10-11.

143 Bucsi, 2011, p. 20.

144 Szeibert, 2019, p. 3.

145 Fehérné, 2016, p. 9.

146 Mentuszné, 2019, p. 22. 


\section{Legal protection and strengthening of a child's family relationships}

The Civil Code attaches great importance to the child's "direct family relationships", that is, it seeks to ensure the rights of those who are de facto involved in the child's care and upbringing and those who provide or have been provided with personal and environmental stability for a long time, even in the absence of blood ties. This is reflected in the rule that entitles a child's stepparent or foster parent-with the consent of the parent exercising parental custody-to exercise certain parental custody rights in the context of care and upbringing of the child. ${ }^{147}$ They can, for example, take part in meetings held at the child's school, go to kindergarten or school for the child, take them to various school events, special classes etc. A person with an actual family relationship with the child is usually the new spouse (stepparent) or de facto partner (foster parent) of the parent exercising parental custody, who is often an active participant in the child's upbringing and care. A foster parent is one who permanently and for a long period of time takes care of a minor child in his or her own household, and he or she is not the biological, adoptive, or stepparent of the child. A foster parent can be the cohabitant of the biological parent who takes care of the child in their own household, but also the third person with whom-if he or she requested-the court has placed the child. This is not altered by the fact that this person must be appointed as the guardian of the child. However, the person who has actual contact with the child may be the new spouse or de facto cohabitant, or the grandparent, aunt, sibling of the parent, or godparent. The importance of the actual family relationship is strengthened by the provision in the Civil Code, which expands the scope of the right to maintain contact with the child to the stepparent, foster parent, former guardian, and the parent whose presumption of paternity for the child has been overturned by a court, provided that the child concerned was raised in their household for a long period of time. The sudden interruption of the intimate relationship between the child and the man he loves as a father can seriously damage the spiritual development and emotional security of the child. This may be particularly important in cases where no one takes the place of the father in the life of the child after the presumption of paternity has been rebutted. ${ }^{148}$

The Civil Code regulates the right and duty of maintenance of non-biological family members. Although the person entitled to maintenance may claim it primarily from his or her immediate relatives, the maintenance of stepchildren, stepparents, and foster parents is an exception to this provision. ${ }^{149}$ The spouse shall provide maintenance in his/her home to his/her spouse's dependent minor child (stepchild) who was brought by his/her spouse to their common home with his/her consent. If the

147 CC. 4:154. §.

148 CC. $4: 113$. $\S(1)$ b).

149 CC. $4: 198$. § and CC $4: 199$. §. 
stepparent has their own children, the entitlement for maintenance shall accrue to the biological children and stepchildren in the same line. However, if the stepparent has objected to the child being brought into the common household, he or she is not obliged to provide maintenance, which means that the child must be maintained exclusively by his or her biological parents. In such cases, the child is usually taken care of by his or her other biological parent. ${ }^{150}$ The entitlement of the stepparent to maintenance is conditional as it depends on whether the stepparent has previously taken care of the maintenance of the stepchild. As reciprocity is the basis for the maintenance of the stepparent, he or she cannot become unworthy of maintenance later. His or her behavior toward the child can only be examined during the infancy of the child and the time spent in the common household, from the perspective of care for the child. The duration and extent of maintenance for a stepparent does not depend on the duration and extent of maintenance for the stepchild.

Maintenance of stepchildren is limited to maintenance in kind and only lasts until the termination of the cohabitation (marriage) of the stepparent and biological parent. A stepparent who lives separately from the child is no longer liable for maintenance in any form. However, the maintenance obligation of the stepparent does not affect the obligation of the biological parent to pay maintenance, that is, the stepparent's maintenance obligation is ancillary to that of the biological parent. In a de facto cohabitation, the consensual upbringing of a child in a common household does not give rise to a maintenance obligation of the cohabitant of the biological parent as a foster parent. In case of voluntary performance, if the spouse of the biological parent continues to take care of the child of his or her partner (foster child) in his or her own household for a long period of time, this behavior-as a foster parent—can give rise to a maintenance claim against the foster child, based on the principle of reciprocity. ${ }^{151}$ Therefore, it must always be examined whether the activities of the foster parent were limited only to the care of the child or if he or she also contributed to the maintenance of the child. If, for example the guardian, as a foster parent, has provided maintenance for a longer period of time at his own expense, he may claim parental maintenance from his foster child. As reciprocity is also the basis of the right of the foster parent to maintenance, this also precludes the possibility of unworthiness in the case of a foster parent. ${ }^{152}$ In light of the foregoing, a foster parent who has cared for a child in the context of child protection care for remuneration cannot claim maintenance. However, the situation is different for a registered partner, as Points a) and b) of Section 3(1) of the Bét. II. state that the rules on marriage shall apply mutatis mutandis to the registered partnership and the rules on the spouse or spouses shall apply mutatis mutandis to the registered partner or partners. Therefore, a child brought into the common household by one of the registered partners with the consent of the other is required to be maintained in kind by the registered partner who is not the non-biological parent.

150 CC. $4: 198$. §.

151 CC. $4: 199 . \S(2)$.

152 Bencze, 2007, pp. 569-570. 


\section{Policy for the protection of the family}

The population of Hungary was the largest in 1980 with almost 11 million inhabitants. However, it has been steadily declining since then. Since 2011, the population of Hungary has fallen below 10 million. To stop the decline of the population, the government initiated a "Family Protection Action Plan" within the framework of which, in addition to classic legal instruments, it introduced a unique family policy that was aimed at increasing the number of marriages and strengthening the desire to have children. The Action Plan includes the development of nurseries, the babybond program, serious tax and contribution reduction for children, and the baby waiting support. Within the framework of the baby waiting support, every firstmarried woman under the age of 40 years can take out a discount loan of 10 million forints for the start of life, which becomes interest-free in case of the birth of one child. In case of two children, $30 \%$ of the debt and in case of three children $100 \%$ of the debt are taken over by the state. The family home foundation allowance is also worth highlighting. It involves state support of up to 10 million forints and a discounted home loan of up to 15 million forints for the creation of a new home in case of three or more children. An important form of support is the baby-care and childcare fee, the latter of which can be used by parents pursuing higher education and by grandparents. The measures initiated for the protection of the family and growth of the population should hopefully achieve the desired result, the appreciation of the work for the family, family formation, and the growing desire to have children.

\section{Summary}

The term "family" is defined in the highest legal source in the Hungarian legal system, namely the Fundamental Law. Marriage enjoys primacy in the Hungarian legal system. However, this does not mean that a same-sex relationship is not recognized or protected, because registered partnerships have similar legal effects. There are some differences in the legal effects of marriage and registered partnerships, such as that registered partners cannot adopt a child jointly and cannot participate in an assisted reproduction procedure. De facto cohabitation is regulated by the Civil Code, but the regulation is dual, because the legislature treats this as a contractual relationship. De facto partnerships will result in family law effects only if the partnership has existed for at least one year and the partners have a common child from their relationship. Kinship connection is based on descent and the father's status can arise in four ways, among which two are not rebuttable: the judicial decision and human reproduction procedures, but the latter can be rebutted only in special cases within the frameworks of strict rules. In Hungary, as there are different ways to 
conceive a child under the eyes of law, a mother's status may be doubtful, especially in the case of surrogacy or nurse pregnancy. But Hungarian law definitely stipulates that a woman giving birth to the child shall be considered the mother of that child. Neither surrogacy nor nurse pregnancy is allowed. 


\section{Bibliography}

ÁDÁмкó, V. (2015) 'Az ítélőképesség birtokában levő gyermek véleményének meghallgatása - különös tekintettel a gyermekelhelyezésre', Családi Jog, 13(3), pp. 10-16.

BAJORY, P. (1957) ‘Az élettárs és az élettársi viszony a polgári ítélkezésben', Magyar Jog, 6(7), pp. 208-213.

BARzó, T. (2017) A magyar család jogi rendje. Budapest: Patrocinium.

BARzó, T. (2017a) 'A családjog alapelvei és érvényesülésük nehézségei’, Miskolci Jogi Szemle, 12(1), Special edition, pp. 37-57.

BARzÓ, T. (2017b) 'A gyermek érdekének védelmét erősítő családjogi alapelv érvényesülésében felmerülő ellentmondások', Opuscula Civilia, 2(2), pp. 2-15. https://antk.uni-nke. hu/document/akk-uni-nke-hu/Opuscula_Civilia_2017_Barzo_Timea.pdf.

BuCSI, Á. (2011) 'A gyermek meghallgatása az ôt érintő eljárásokban - egy alapelv érvényesülése a magyar joggyakorlatban’ I. part, Családi Jog, 9(2), pp. 17-26.

BuKODI, E. (2002) 'Házasság vagy élettársi kapcsolat: ki mikor mit (nem) választ', Statisztikai Szemle, 80(3), pp. 227-251.

CsıKY, O. (1973) A gyermek családi jogállása. Budapest: Közgazdasági és Jogi Kiadó.

CsÛRI, É. (2010) 'A bejegyzett élettársi kapcsolat és az élettársi viszony igazolása', Ügyvédek Lapja, 49(4), pp. 13-21.

CsÚRI, É. (2016) Házassági vagyonjog az új PTK-ban. (4:34.§ - 4.85.§) Házassági vagyonjog. Budapest: Opten Informatikai Kft. Kiadó.

DARNót, S. (2017) 'A gyermek meghallgatás a családjogi perekben', Családi Jog, 15(4), pp. 20-24.

GYENGÉNÉ NAGY, M. (2018) 'A gyermek mint érintett részvétele a közvetítői eljárásban', Családi Jog, 16(4), pp. 2-9.

FEHÉRNÉ GAÁL, T. (2016) 'Gondolatok a kiskorú gyermek véleménynyilvánításának és meghallgatásának elkerülhetetlenségéről a szülői felelősséget érintő perekben - a Budapest Környéki Törvényszék és a területéhez tartozó járásbíróságok gyakorlata alapján', Családi Jog, 14(2), pp. 7-15.

HEGEDÛs, A. (2006) 'Az élettárs fogalma és a kifejezés tartalmi vonatkozásai', Családi Jog, 4(4), pp. 10-16.

HEGEDÚs, A. (2010) Az élettársi kapcsolat a polgári jogi kodifikáció tükrében. Szeged: Pólay Elemér Alapítvány.

HEGEDÚs, A. (2008) 'Az élettársi kapcsolat vagyonjogi vonatkozásai’, Családi Jog, 6(1), pp. $11-19$.

HerCzoG, M. (2020) 'Anya csak egy van? Az asszisztált reprodukció gyermekjogi megközelítésben', Családi Jog, 18(2), pp. 45-50.

KATONÁnÉ PeHr, E. (2007) Az örökbefogadás. In: A családjog kézikönyve 2007 I. Vol (ed.: Kőrös András) Budapest: HVG-Orac Kiadó.

KATONÁNÉ PEHR, E. (2020) 'A gyermek érdeke az örökbefogadás új jogi környezetében. A gyermekközpontú örökbefogadás követelménye’, Családi Jog, 18(3), pp. 1-8.

KőRÖs, A. (2005) ‘„Fontolva haladás” - az új Ptk. Családjogi Könyve, 1. part: Az élettársi jogviszony szabályozásának szakértői javaslata’, Családi Jog, 3(2), pp. 1-10.

Kőrös, A. (2013) Alapelvek. In: Az új Ptk. magyarázata III/VI. Polgári Jog Családjog (Ed. Kőrös, A.) Budapest: HVG-ORAC Lap és Könyvkiadó.

KöRÖs, A. (2013a) 'Az új Ptk. Családjogi Könyve - a 2013. évi V. törvény és a Szakértői Javaslat összevetése. Első rész: Alapelvek, Házasság, Élettársi kapcsolat', Családi Jog, 11(3), pp. 1-8. 
Kőrös, A. (2008) 'Fontolva haladás - az új Ptk. Családjogi Könyve 12. Part: Az örökbefogadás I.', Családi Jog, 6(1), pp. 2-10.

KRISTON, E. (2018) 'A család fogalma a társadalmi innováció súrújében, különös tekintettel a jogi és szociológiai megközelítésre', Publicationes Universitatis Miskolcinensis Sectio Iuridica et Politica, Tomus 36(2), pp. 396-407.

KRISTON, E. (2016) 'Az élettársak megítélése az alkotmányjog é a polgári jog szempontjából', Publicationes Universitatis Miskolcinensis Sectio Juridica et Politica, Vol. 34, pp. 226-239.

KRISTON, E. (2014) 'Az élettársi kapcsolatok szabályozása az új Ptk. tükrében', Advocat, 2014(1-2).

KRISTON, E. (2018) 'A de facto élettársi kapcsolat elmélete és gyakorlata - fogalmi nehézségek (I. part).', Advocat, 21(4), pp. 4-7.

KRISTON, E. (2019) 'Relationship Form in the Comtemporary Hungary - in the Light of the European Trends' in Králíčková, Z., Kornel, M., Valdhans, J. (eds.) Days of Law 2018. Part one - Marriage for all? Acta Universitatis Brunensis Iuridica edition Scientia, Brno: Masaryk University Press.

KRISTON, E. (2019) 'A család megítélése Európában, különös tekintettel az azonos nemú párok helyzetére' in Szabó, M. (ed.) Studia Iurisprudentiae Doctorandorum Miskolciensium - Tomus 18. Miskolc: Bíbor Kiadó.

Kun, A. (2018) 'Az apaság vélelmének megdöntése nemperes eljárásban', Családi Jog, 16(1), pp. 38-40.

KuTI, Sz. (2016) 'Párkapcsolati formák Magyarországon. Élettársak a közjegyző előtt „születéstől a halálig”, Közjegyzők Közlönye, 63(1), pp. 5-50.

LÁBADY, T. (2014) A házastársi tartás. In: Családjog a 2013. évi V. törvény alapján. Az új Polgári Törvénykönyv szövegének rövid magyarázata (Ed. Csehi Zoltán) Budapest: Menedzser Praxis Kft.

MÉCSNÉ, BUJDOSó GY. (2000) 'Ki az apa? A származásmegállapítás hagyományos és modern vizsgáló módszerei', Magyar Jog, 47(7), pp. 425-429.

MENTUSZnÉ TERÉK, I. (2019) 'A szülőii felügyelet korlátozása a gyermek családjából való kiemelésével - jogi szabályozás és gyakorlati kérdések', Családi Jog, 17(4), pp. 15-22.

NAVRATYIL, Z. (2012) A varázsló eltöri pálcáját? A jogi szabályozás vonulata az asszisztált humán reprodukciótól a reproduktív klónozásig. Budapest: Gondolat Kiadó.

NizSALOVSZKY, E. (1963) A család jogi rendjének alapjai. Budapest: Akadémiai Kiadó.

NovÁK, R. (2016) 'A 19. és 20. megálló egy barátságosabb és igazságosabb világ felé? az azonos nemúek államilag elismert életközösségével és házasságával kapcsolatos jogi változások, különös tekintettel a 2015. év eseményeire', Családi Jog, 14(1), pp. 29-37.

PÁL, Sz. (2016) 'Tényállások a házassági bontóperben. A sehova kapuja?', Családi Jog, 14(1), pp. 17-23.

RÁCZ, L. (2019) 'A család és a családtagok viszonyának magánjog-tudományi beágyazottságáról', Családi Jog, 17(4), pp. 31-35.

SOMFAI, B. (2006) ‘A gyermek „származáshoz való joga”', Család Gyermek Ifjúság, 15(6), pp. 6-12.

SPÉDER, Zs. (2004) Gyermekvállalás és a párkapcsolatuk alakulása. In: Társadalmi riport 2004, Kolosi Tamás, Tóth István György, Vukovich György (ed.). Budapest: TÁRKI.

SZABÓ-TASI, K. (2012) 'Méheknek gyümölcse - a dajkaanyaság intézménye bevezetésének jogi dilemmáiról', Családi Jog, 10(1), pp. 7-14.

SzeIBERT, O. (2004) ‘Az élettársak jogállása’, Polgári Jogi Kodifikáció, 6(3), pp. 17-20.

SzEIBERT, O. (2013) Az élettársi kapcsolat családjogi hatásai. In: Kőrös András (ed.): Az új Ptk. magyarázata III/VI.: Polgári jog. Családjog. Budapest: HVG-ORAC Lap- és Könyvkiadó Kft. 
SzEIBERT, O. (2013) ‘Az új Ptk. Családjogi Könyvének rendelkezései. II. part. Szülői felelősség, örökbefogadás, gyámság, gyermektartás’, Jegyző és közigazgatás, 15(5), pp. 30-32.

SzEIBERT, O. (2012) 'Élettársi vagyonjog: az ítélkezési gyakorlat állása 2012-ben. Újabb ítéletek és kérdések' in Szeibert, O. (ed.) Család, gyermek, vagyon. A joggyakorlat kihívásai. Családjogi tanulmánykötet, Budapest: HVG-ORAC Lap- és Könyvkiadó Kft.

SzEIBERT, O. (2019) 'A gyermek meghallgatása/véleménye, a gyermektartás, az élettárs szülők helyzete és az ötéves Ptk. - vitatható gyakorlatok', Családi Jog, 17(3), pp. 1-8.

TóTH, Á. (2003) 'Az élettársak jogainak bővítéséről', Családi Jog, 1(2), pp.12-18.

VARGA, T. (2020) 'Az apai elismerés elméleti és jogalkotási dilemmái, megjelenése a közigazgatási jogalkalmazásban', Családi Jog, 18(2) pp. 22-29.

VÉKÁs, L. (2013) 'Bírálat és jobbító észrevételek az új Polgári Törvénykönyv kapcsán (zárószavazás előtt)', Magyar Jog, 60(1), pp. 1-7.

VISONTAI-SzABÓ, K. (2021) 'A házassági krízisek pszichológiai háttere és néhány megoldás a békés válás érdekében’, Családi Jog, 19(1), pp. 1-8. 